BISNIS \& BIROKRASI: Jurnal Ilmu Administrasi dan Organisasi

Volume 28

Number 1 Volume 28 No. 1 (January 2021)

Article 5

June 2021

\title{
The Perception of Actors Toward Collaboration in Public Services: Evidence from Civil Registration Services Innovation in the Pangkajene and Island Regency
}

Krisna Puji Rahmayanti

Faculty of Administrative Science, Universitas Indonesia

Follow this and additional works at: https://scholarhub.ui.ac.id/jbb

Part of the Public Administration Commons

\section{Recommended Citation}

Rahmayanti, Krisna Puji (2021) "The Perception of Actors Toward Collaboration in Public Services:

Evidence from Civil Registration Services Innovation in the Pangkajene and Island Regency," BISNIS \& BIROKRASI: Jurnal IImu Administrasi dan Organisasi: Vol. 28 : No. 1 , Article 5.

DOI: 10.20476/jbb.v28i1.1297

Available at: https://scholarhub.ui.ac.id/jbb/vol28/iss1/5

This Article is brought to you for free and open access by the Faculty of Administrative Science at UI Scholars Hub. It has been accepted for inclusion in BISNIS \& BIROKRASI: Jurnal Ilmu Administrasi dan Organisasi by an authorized editor of UI Scholars Hub. 


\section{The Perception of Actors Toward Collaboration in Public Services: Evidence from Civil Registration Services Innovation in the Pangkajene and Island Regency}

\section{Cover Page Footnote}

This research is part of collaborative governance in a public services project that was managed and funded by the Local Autonomy Directorate, The Ministry of National Development Planning, Republic of Indonesia. The researcher appreciates the informants and respondent willingness to join focus group discussion and fill the survey as well as the support of the Pangkajene and Island Regency. Researcher is consultant of this research project that advocates in research design development and data collection to nine case study locations including Pangkajene and Island Regency. Author appreciated Salma's assistance in manuscript editing. 


\title{
The Perception of Actors Toward Collaboration in Public Services: Evidence from Civil Registration Services Innovation in the Pangkajene and Island Regency
}

\author{
Krisna Puji Rahmayanti \\ Faculty of Administrative Science Universitas Indonesia, Indonesia \\ krisnarahmayanti@ui.ac.id
}

\begin{abstract}
This paper aims to analyze the perception of involved actors toward collaboration and investigate conditions that motivate actors to collaborate in delivering public services. This study uses pragmatic philosophy that utilizes qualitative data collection. Despite the government as the leading service provider, non-state actors' involved in planning, organizing, and evaluating service delivery. By conducting a focus group discussion, providing an open question survey, and analyzing relevant news, this research emphasizes that public service providers and communities involved in public service delivery perceived collaboration as working with others or cooperating and achieving common goals. The actors' belief that achieving common goals is the driver to collaboration. The result also found that developing policies and legal framework to strengthen collaboration is essential to sustain the collaboration.
\end{abstract}

Keywords: Collaboration, Public Services, Motivation, Indonesia

\section{INTRODUCTION}

The public services reform promotes an increasing degree of stakeholders' involvement as New Public Services defines new terms of public service delivery that go beyond contractual relationship or privatization in New Public Management. As a result, the discussion of collaborative governance emerged as an increasing trend of multi-actor involvement in solving wicked problems. Collaborative governance is an arrangement of several institutions and actors (state and non-state) in decision making or program management (Ansell \& Gash, 2007, p. 544). Collaborative governance is a transformational process to improve the quality of public services (O'Flynn \& Wanna, 2009 , p. 181). The various researcher provides logic thinking of collaboration, such as a clear mission and goals, a flexible bureaucratic procedure, and an incentives to guarantee commitment (Bardach, 1998); problem definition, previous collaborative experience, and Standard Operating Procedures (SOP) (Daley, 2008); regulatory element, facilitative leadership, governance, and power imbalance (Bryson, Crosby, \& Nabatchi, 2006); systematic context, power, regulatory framework, prehistoric condition, and collaborative process (Emerson \& Nabatchi, 2015) (Emerson \& Nabatchi, 2012); and starting conditions or information imbalance and prehistoric to collaboration, institutional design, leadership, and collaborative process (Ansell and Gash, 2007). With the logic of collaboration, the starting condition is essential in understanding the willingness to collaborate (see starting condition in Ansell and Gash (2007), initial conditions in Bryson, Crosby, and Stone (2006), and prehistoric condition in Emerson \& Nabatchi (2015).

One of the early elements that influence the initial conditions to collaboration is the motivation to collaborate or awareness or willingness. There has been a variety of research with various theoretical explanations from multiple angles such as prisoner's dilemma (Esteve, Van Witteloostuijin, \& Boyne, 2015), agency theory, game theory, gender theory, and public choice theory to describe motivations for collaboration at the individual, group, or sector level (Gazley, 2008). Previous research reviewing public service motivation and desire for collaboration found a strong link between public service motivation measured and collaboration behavior at the individual and organizational levels (Getha-Taylor \& Haddock-Bigwarfe, 2014; Esteve, Van Witteloostuijin, \& Boyne, 2015; Nikolova, Postmus, Buttner, \& Bosk, 2020). In addition, the study of cultural theory found that values play a vital role in guiding public managers in collaboration (Conner, Nowlin, Rabovsky, \& Ripberger, 2015).

This study presents original data from an open question survey, a focus group discussion, and secondary data to examine the perceived definition of collaboration and motivation to collaborate at the organizational levels among a sample of civil registration services at the Pangkajene and Island Regency, a local government in Indonesia. Collaboration in delivering civil registration service is important in the area, which involved several government agencies and non-government organizations in increasing the services coverage and citizen awareness. To this end, this work seeks to answer the following research questions: How do the actors define collaboration? And what motivates the actors to collaborate in delivering public services?

Attempting to answer the research question, the structure of this article consists of a literature review of collaboration, research method, result, discussion, and conclusion. First, the literature review consists of the definition of collaboration and motivation to collaborate. Next, the article explains the research 
methods used for data retrieval. Then, in the analysis section, there is an explanation of case study, perceived definition of collaboration, and motivation to collaboration. Eventually, the conclusion provides a resume and synthesizes the argument of the research.

\section{Collaboration}

Collaboration has become a study in various sectors and one of them is part of governance studies. Governance is considered to be able to answer two challenges: overloaded government and ungovernable society (Peters \&Pierre, 2006). Overloaded government is the inability of the government to respond all expectations and demands from the public. If overloaded government is a picture of government capability, the ungovernable society is more on complex public characteristics. The governance itself concern about solving complex problems through the involvement of all sectors. Collaboration is becoming an increasingly common practice in the public sector as the complexity of governance increases. Working with more than one agency or well-known for the term collaboration is increasingly becoming an expectation for public managers (Agranoff, 2007; Thompson \& Perry, 2006). Public sector managers often claim that working with organizations across agencies to respond to social needs (O'Leary \& Bingham, 2009) emphasizes various models of collaboration in public services.

Collaborative governance is defined by Ansell and Gash (2007) as a governing arrangement that involves non-governmental stakeholders to work together through a given process in the management of public affairs. Meanwhile, Emerson, Nabatchi and Balogh (2012) defined collaborative governance as a public policy-making and public management process, the undertaking of which involves stakeholders from the outside of governmental institutions, such as the community, private sector and civil society, for the purpose of achieving public goals. In collaborations, conflicts among stakeholders are common. This is due to the fact that collaborations are complex, with different parties viewing collaborative processes in clashing perspectives (O'Flynn \& Wanna, 2009). Despite that, it is the purpose of collaborative governance to turn relations at risk of disagreement into ones that are more cooperative in nature.

In terms of actor's collaboration can be implemented between governments and with nongovernment parties. Non-governmental parties in collaboration can be individuals or non-governmental organizations. Agranoff (2007) explicitly stated that pubic networks could collaborate with representatives of public agencies and NGOs to address common problems. More broadly, Emerson, Nabatchi, Balogh (2012) said that collaboration in collaborative governance engages people from public, private, and civil spheres in various structure levels. Collaboration in terms of collaborative governance is arranged both in formal and informal relationships in public and private sectors as a governance system of administrative, judicial judgment, and regulatory actions to provide public goods and services (Lynn, Heinrich, \& Hill, 2001).

In term of collaboration, there are several trends of discussion such as collaborative process. Collaborative governance as a process at least appears in research that emphasize the importance of collaborative process (Ansell \& Gash (2007), Thomson \& Perry (2006), Emerson \& Nabatchi (2015)). Emerson \&Nabatchi (2012) sees collaborative governance as a process that occurs in the context of the system and involves collaborative governance and collaboration dynamics to generate impact as an outcome. Meanwhile, Ansell \& Gash (2008) sees collaborative governance as an input, process, and output system with inputs derived from prehistoric collaboration. The same also appears which illustrates illustrating collaborative governance as a relationship between collaborative processes, outputs, and outcomes. The collaboration process all leads to output and outcome and there are a number of variables that affect the collaboration process (Ansell \&Gash, 2007; Emerson \&Nabatchi, 2015).

Scholars used various terminology to express the type of collaboration. However, most scholar seems agreed to identify a typology of collaboration as a degree. The governance forms perspective identifies collaboration from contracts to partnerships or networks (Thompson, Frances, Levacic, \& Mitchell, 1991). Sullivan and Skelcher (2002) identify forms of collaboration that start from the network, partnership, federation, and integration. In comparison, Mandell $\&$ Steelman (2003) identify inter-organizational innovations from intermittent coordination, temporary task force, permanent and or regular coordination, coalition, and network structure. Classification of collaborative tools conducted by Mandell \&Steelman (2003) indicates that collaboration can be carried out between public institutions at various levels of government (direct government services) or collaborations that involves non-governmental organizations (regulation).

\section{Motivation to collaboration}

There are two levels to measure motivation in collaboration, namely at the organizational level and the individual level (Getha-Taylor \& Haddock-Bigwarfe, 2014; Nikolova, Postmus, Buttner, \& Bosk, 2020; Esteve, Van Witteloostuijin, \& Boyne, 2015). At the organizational level, the drive for collaboration arises from awareness of the importance of resource and experienced personnel sharing; the need for organizational contributions; the importance of multi-agency and multidisciplinary work, the presence of leadership support, and the need to achieve organizational goals. At the individual level, the motivation for collaboration can be measured by looking at each individual's desire to leave their state, take paid leave, or give up free time to collaborate. This research builds upon the understanding of the organizational level of motivation and provides an opportunity to expand 
Table 1. Measure of Motivation to Collaborate

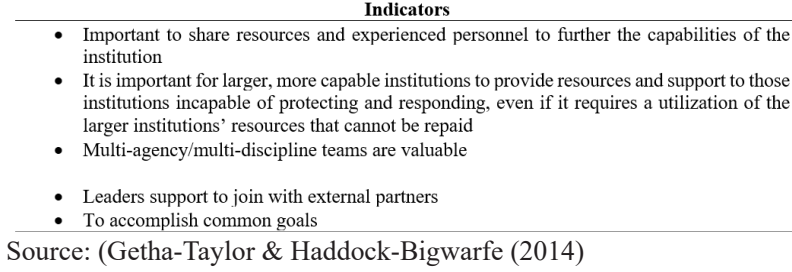

the organizational level of motivation to collaborate based on empirical data (Getha-Taylor \& HaddockBigwarfe, 2014).

Researchers found an influence on the condition of organizations and individuals on the desire to collaborate. A dataset survey in the United States found that while organization collaboration factors increase workers willingness to cooperate, the workers' professional efficacy becomes a mediating or moderating factor (Nikolova, Postmus, Buttner, \& Bosk, 2020). This research shows individual characteristics such as workers attitude, experience, salary, and history of problems are also influential in shaping collaboration (Nikolova, Postmus, Buttner, \& Bosk, 2020). A study using survey data and hierarchical multiple regression also found a strong relationship between public service motivation measures and attitudes toward collaboration at the individual and organizational level (Getha-Taylor \& Haddock-Bigwarfe, 2014). A study in the public cooperation with police found that procedural justice is more important to youth for encouraging youth's cooperation with police (Murphy, 2015). The procedural justice in Murphy (2015) study conceived as two dimensions concept that relates to the quality of treatment people receives from authorities and the quality of decision-making people receive from authorities (Reisig, 2007). The Murphy study shows that a good precedent for previous experience with parties who will work together influences decisions in conducting collaboration.

\section{RESEARCH METHOD}

This study uses pragmatic philosophy by using qualitative data collection. The author chose qualitative research methods to obtain a deeper picture. Qualitative data collection seeks to analyze social life by describing the social world from the perspective or interpretation of individuals (informants) to investigate the individual's view of the social world. This study is also expected to add to the findings of previous research conducted quantitatively, such as Nikolova research (2020) on domestic violence issues, Murphy (2015) on collaboration with the police, or research Getha-Taylor \&Haddock-Bigwife (2014) with the context of homeland security.

The author invited actors involved in the GERTAK program to a focus group discussion. Thirty participants attended the semi-structured discussion consisting of nine active informants and twentyone observer representing the public and non-profit institution in Pangkajene and Island Regency. The
Table 2. Data Collection Overview

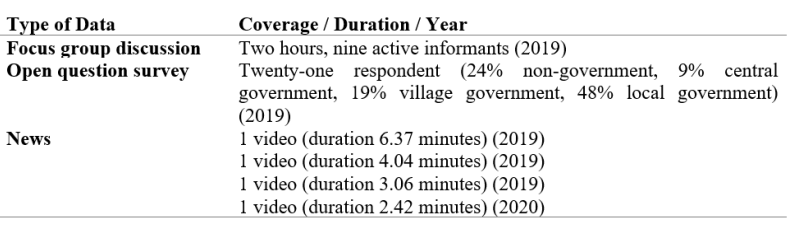

researcher screened the institution's name involved in the program through internet searching and validated the list with the local government (Regional Development Agency/Bappeda). The discussion gives each institution equal opportunity (time) and several participants became active participant or observer. The discussion was conducted in the Indonesian language, in which all interviewees and the researcher were fluent. Prior to the discussion, the participants got research information and informed consent to join the focus group discussion and fill in the survey. The survey utilizes open questions, which consist of two questions: how do you define collaboration and what motivates you to participate in the GERTAK program. Twenty-one surveys were returned, indicating a $70 \%$ per cent response rate. In addition, the author reviewed relevant news from four video publications between 2019-2020. The researcher transcribed the focus group discussion and analyzed the data using NVivo. The analysis considers the willingness to collaborate measurement at the organizational level from Getha-Taylor \& Haddock-Bigwarfe (2013) as the initial code. The researcher creates new code for surprising code in two main themes: definition of collaboration and motivation to collaborate.

This study is part of a collaborative governance study that the Ministry of Development and Planning commissioned. The study consists of nine different case study location around Indonesia, and the GERTAK program is one of the case studies. There was no ethical board review for this research; however, the research conducts a focus group discussion to evaluate the survey instrument and focus group discussion guide. The development of the study instrument also under peer review of practitioner and research colleague at the university. The researcher provides research information and informed consent for each data collection.

\section{RESULT AND DISCUSSION}

\section{The Overview of Case Study}

This research aims to draw empirical evidence from Indonesia as a developing country with various challenges to provide qualified public services. Indonesia has just risen to the upper-middle-income category based on the World Bank classification for 2020-2021 (Serajuddin \&Hamadeh, 2020). World Governance Index 2019 notes that the effectiveness of the Indonesian government is much higher than other middle-income countries but still far from the percentile rank of the high-income country (Kaufmann, Kraay, \& Mastruzzi, 2010). Although the value of government effectiveness is high compared 
to middle-income countries, this indicator cannot describe the performance of public services in Indonesia. The Ombudsman evaluated several ministries/agencies/and local governments compliance in meeting public service standards and found $40.47 \%$ were in the medium compliance category and $26.51 \%$ were in the lowest compliance of the 214 districts that sampled (The Ombudsman Republic of Indonesia, 2019). The results of the compliance analysis of this service standard illustrate that service standards alone are still inadequate.

The sample of interest in this study is public service under the GERTAK program at the Pangkajene and Island Regency, a local government in Indonesia. Pangkajene and Island Regency are home to 3.79\% of the population in South Sulawesi Province. The population density in this district is twenty eight times lower than Makassar City, which has the highest population density in South Sulawesi Province. The population live in thirteen sub-districts, with nine subdistricts on the mainland of the island of Sulawesi, and every four sub-districts are on the island. The farthest island is $291.29 \mathrm{~km}$ and estimated to take two days and two nights to reach by boat from the center of the district's capital (Statistics of Pangkajene and Island Regency, 2018).

The GERTAK program is a public service in Pangkajene and Island Regency aims to increase civil registration coverage such as proof of residence, birth certificate, marriage certificate, divorce certificate, and many others. The basic principle of this service is to bring population and civil registration services closer to the community by carrying out mobile services to both villages and schools by involving several government agencies and non-government organization. In the world, the regions with the highest birth certificate ownership rates were Western Europe $(100 \%)$ and North America $(100 \%)$, while the regions with the lowest ownership were Easter and Southern Africa (40\%) (UNICEF, 2020). In comparison, Indonesia has only reached $72 \%$ (Central Bureau of Statistics, 2018). Analysis of complaints on social media still found various problems in the population administration service (Nugraheny, 2020).

Initially, Pangkajene and the Island Regency District Population and Civil Registry Office with Community Collaboration and Services for Welfare (KOMPAK) initiate the GERTAK program, which has been implemented since 2017 (KOMPAK, 2019). The GERTAK program agreement was carried out through an MoU between the Civil Registry Office, the Religious Courts and the Ministry of Religious Affairs and was witnessed by the Regent of Pangkajene and Island Regency. The Civil Registry Office is an institution that has a significant role in civil registration services. Several other government agencies are involved, including the Religious Courts, the Office of Religious Affairs, the Education Office, Health Facilities, Village Government, and Regional Planning and Development Board (Bappeda). The Coordinator of Civil Registry (kordukcapil/ volunteer) under The Civil Registry Office promotes the awareness of civil registration services. The role of the village in this program is essential; as stated by the Mattiro Baji Village Government in the focus group discussion that the village government established the Village Service Post as a forum to serve the community's administrative needs. The commitment of the village government, especially the villages located on the island, consistently continued the following year to provide civil registry service in cooperation with the Civil Registry Office (Communication and Information Agency, 2020). There are also roles of the non-state actor, which is funded by donors such as KOMPAK, YASMIB, and Lembaga Maritim Nusantara (LEMSA) (KOMPAK, 2019). Universities are also involved in indirectly implementing thematic student study service (Kuliah Kerja Nyata), which eventually supports the provision of these services (PANGKEP TV, 2020). KOMPAK also initiated a thematic student study service to increase the awareness of the civil registry service in the West Nusa Tenggara province (KOMPAK, 2020).

\section{The Actors Perception of Collaboration}

Understanding the concept of collaboration between institutions is essential in the process of collaboration. The informants who attended the focus group discussion and were willing to answer questions about the definition of a collaboration mostly noted that collaboration is cooperating with other agencies and achieving common goals. The definition of collaboration can be seen as the type of actor perceived as a collaboration partner. Types of organizations involved include government from various levels to village administration, non-government organizations, and citizens. In terms of numbers, everyone agrees that collaboration is done plurally with two or more parties. The implementation can also be done individually or organizationally.

The representative of the non-governmental organizations at the focus group discussion defined collaboration as a jigsaw, "GERTAK collaboration is like a puzzle that brings together pieces of the potential of each institution to serve the needs of population and civil registration services in Pangkajene and Island Regency (Non-Governmental Institutions statement in Focus Group Discussion)". Representatives from the Village Government underlined that collaboration exists in community activities, "Collaboration is a cooperation in terms of implementing activities based on an agreement. The actors who are involved are the community and village government (Village Secretary statement in Focus Group Discussion)". These statement in line with another perspective which understanding collaboration as working with other organization as stated by these two informants:

"Collaboration is a process of teamwork with various parties to obtain common results / goals" (Head of Program, Regional Development Agency statement in Focus Group Discussion) 
Table 3. Regulation Perspective of Collaboration in Indonesia

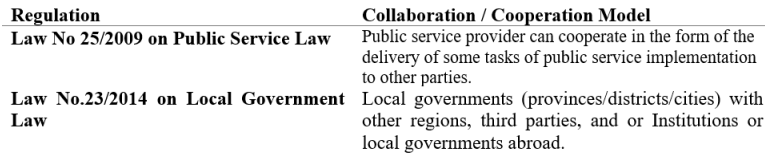

Source: Law No 25/2009 and Law No 23/2014

Teamwork between two or more actors, either within one agency or between agencies, in order to provide services for the community to achieve the goals or vision and mission of an agency (Head of Administration, Ministry of Religion, Pangkajene Regency statement in Focus Group Discussion).

The actors involved stated that there is a lower to a higher level of collaboration. Informants from government agencies also agreed that collaboration is an activity that involves more than one person and several institutions to achieve common goals. The informants used terminology cooperation to describe collaboration is common since the government used cooperation in the regulations such as Public Service Law and Local Government Law. The regulation reviews the involvement of various institutions using the terminology of cooperation rather than collaboration. The regulatory framework in Indonesia pushes the government at all levels to increase collaboration, especially in public services. Collaboration, or often the government used terminology 'cooperation' in regulation, in public services can be conducted if there are limited resources and emergency (Article 12 Paragraph 3, Law No.25/2009 of Public Service Law). The Public Service Law states that the organizer can cooperate by handing over some of the duties of public services to other parties (Article 13 paragraph 1, Law No.25/2009 of Public Service Law).

The public service law makes it clear that service providers can cooperate with other parties. The provisions of cooperation in public service law include the organizer is obliged to formulate a cooperation agreement to the community. Other parties that become cooperation partners must be incorporated in Indonesian law. The responsibility of the implementation of cooperation lies with the recipient of the cooperation, while the responsibility of the overall implementation lies with the public service provider. The organizer must list information about the identity of the other party and the organizer's identity as the person in charge of the activity in a clear and easy-to-know place of the public. Public service provider and other parties must include the address of the complaining location and the means to accommodate accessible public complaints, among others, telephone, short message service (SMS), website, e-mail, and complaint box.

A further systematic comparison is necessary, but from significant characteristic of the current collaboration, the case study collaboration is similar to the type of partnership (Thompson, Frances, Levacic,
\& Mitchell, 1991), partnership (Sullivan \& Skelcher, 2002), and intermittent coordination (Mandell \& Steelman, 2003). The government and non-government organization involved in planning, organizing, controlling, and leading process of service delivery. The Civil Registry Office as the agency that holds a coordinating role makes efforts to involve various other agencies, for example the Health Office and the Education Office, to carry out socialization efforts and documents registry through the duties and functions of these offices. Non-government institutions are also involved in the planning, discussion process and implementation of direct services. As a result of the discussion, it was found that non-governmental organizations had a major role in planning and initiating the project, carrying out the process of socialization and assistance for the community, especially for people living on islands.

The provisions on cooperation in public services are also stipulated in the Local Government Law and Government Regulation No. 28/2018 as illustrated by table 3 . Assembly at provincial or municipal level has a role to be an institution that gives approval to the model of collaboration conducted by the local government. The local government law states that the government can cooperate with consideration of the efficiency and effectiveness of public services and competitive benefits. Cooperation with other regions can be mandatory cooperation or voluntary cooperation. Mandatory cooperation can be carried out by geographically adjacent regions for the implementation of government affairs with cross-regional externalities and the efficiency of public service provision. Voluntary cooperation is carried out by neighboring regions or not to organize government affairs more effectively and efficiently. Government Regulation No.28/2008 on Local Government Cooperation becomes a derivative regulation that explains in more detail the mechanism of local government cooperation.

Collaboration is not only public sector domain as recent study found that public value creation through cross sector collaboration is also private sector domain (Kurniawati \& Kustulasari, 2020). In Indonesia itself there have also been various forms of innovation in population administration services that include joint work between governments and non-governmental organizations (Civil Registry Office Metro City , 2020; Directoral General of Popuation and Civil Registry Ministry of Home Affairs, 2020). Non-government parties also have a precedent of collaborating with the government in population administration services as done between Civil Registry Office Denpasar and GOJEK (an on demand multi service tech platform providing access for transport (Civil Registry Office Denpasar City, 2020). KOMPAK as a facility funded by Government of Australia to support the Government of Indonesia also provide advocacy in civil registration service in collaboration with local governments in Indonesia such as East Lombok Regency (Annissa, 2019). 


\section{Motivation to Collaboration}

The initial conditions that drive a collaboration have been the focus of the study of various academics. This study analyzed the perception of actors involved in collaboration about the conditions that cause collaboration in the GERTAK program. The study found that the central theme often referred to by informants is collaboration to achieve common goals. Various common purposes perspectives can be identified, namely solving problems, organizing services, achieving better outcomes, and improving access to services.

The problem in citizen registration service emerges from two reasons, namely geographical challenge and social-cultural condition. Some informants often cited that this district is a 'three-dimensional area' that is a region with geographical conditions of islands, mountains, and lowland. The geographical situation of Pangkajene and Island Regency, which has four sub-districts on the island, places residents living in this region complex to reach the service center in the district capital.

The geographical problem encourages the government to innovate and collaborate, as stated by program innovator in an interview in 2019: "We face obstacles, for example, firstly, a road, and the second is geographical location. Pangkajene and Island district is a three-dimensional area consisting of lowland, mountainous areas, and islands. This makes something that.. distance.. which is far from the service centre, so we took the initiative to visit residents where the area is not yet reachable by vehicle. For example, to the mountain Well, it's still necessary to struggle. Secondly, it's an archipelago, well it's still using boats. We'll all we do for the sake of the Pangkajene community to get civil documents. The best solution is that we as service providers provide services to the community to the maximum and it is possible to no longer complain about the costs incurred so that we so we issue the residence documents with all efforts for free" (Unit Head of Civil Registry Office interview in a news publication, 2019).

Secretary of Civil Registry Office also confirmed that the agency expands the innovation in November 2019 to solve the geographical challenge as mentioned in preparation of technical guidelines for programs in cooperation with KOMPAK on 28th November 2019: "The condition of our area in Pangkep (Pangkajene and Island Regency) consists of three dimensions are mountain islands and land so to facilitate that we form these three programs aim to solve that problems" (Secretary of Civil Registry Office interview in a news publication, 2019).

They are solving the geographical challenge similar to increase access to services. Difficulty in accessing services can occur due to travel costs, availability of transportation, long journeys to service centers, all of which ultimately can delay services. The people in the islands are recognized as the priority of this program because of the difficulty accessing transportation and communication. The Civil Registry Office has a vital role in the service, serving approximately 329,791 people in sixty-five villages and thirty-eight subdistricts twenty-eight villages and four sub-districts located in the regency (Statistics of Pangkajene and Island Regency, 2018).

The focus group discussion also highlighted that the socio-cultural condition of the community that is still permissive over early marriage often becomes the reason behind the problem in civil registration services. Early marriage encourages the people not to record the marriage and follows does not record in case of divorce or birth of the marriage. Although the Ministry of Religious Affairs has banned marriages under 19 years (women) and 21 years (men) but the practice of early marriage is still rampant in Pangkajene and Island Regency (Dwiastono \& Budhi, 2019). The informant mentioned that several citizens have been married for a long time but do not have a marriage certificate. It is recognized that there is already a Marriage Information System (SIMKA) that facilitates the public and the government in recording marriages. The GERTAK program provides the solution for this problem by inviting all relevant agencies to one integrated service.

The better outcome from an actor's perspective is the increase of citizen registration coverage. The regional government acknowledges that there has been an increase in population and civil registration ownership since implementing the GERTAK program. From May 2017 to May 2018, the regional government stated a rise in e-KTP ownership by $39.4 \%$, birth certificates by $31 \%$, and family cards by $21.7 \%$. The increased number of ownerships shows an improvement compared to the period before the program, which still recorded minimal ownership of population and civil registration.

Literature asserts that shared goals are a key factor in collaboration. Scholar used shared understanding terminology as an element of the collaboration process that emphasize a clear mission, common definitions of the problem, and the exact identification and values (Ansell \& Gash, 2007, p. 560). Having the same goals influences collaboration. The understanding of the problems or experience to the problem has proven to influence the desire to collaborate (Nikolova, Postmus, Buttner, \& Bosk, 2020). The same goals here is not an identic purpose but within a network of actors that have different duties and responsibilities in dealing with context. For example, in the study of disasters there needs

Table 4. Motivation to Collaborate in the GERTAK Program

\begin{tabular}{lc} 
Indicators & Reference \\
\hline Important to share resources and experienced personnel to further the & 3 \\
capabilities of the institution & 1 \\
Multi agency and multi discipline are valuable & 22 \\
To accomplish common goals & \\
a. Solved problem (geographical challenge, social-cultural) & \\
b. Service delivery & \\
c. Better outcome & 2 \\
d. Better access & 1 \\
Sustainability & 2 \\
Reduce bureaucracy & 3 \\
Legal framework & \\
Accomplish institution goals & \\
a. Medium of citizen aspiration and voice & \\
b. Relevant to agency role and function &
\end{tabular}


to be a goal, vision, and mission of the organization that is in line so that the network relationship is stable and sustainable (Kapucu, Garayev, \& Wang, 2013, p. 122). A recent study which combined five types of research about factors to collaborative governance (Bardach (1998), Ansell \& Gash (2007), Daley (2008), Bryson, Crosby, and Stone (2006), Emerson $\&$ Nabatchi (2015)) underlined issue salience as one of the factor which imply that the understanding of the problems potentially influence the collaboration (Mu, de Jong, \& Koppenjan, 2019).

The collaboration initiative also inspired by the need for resources sharing. The division of authority place the Civil Registry Service Office as a responsible agency to provide this service with the only institution with a specific fund for population data services. Other institutions, despite their motivation to address the problem, still have no specific budgets and resources for providing civil registry service. Non-governmental organizations are more flexible in collaboration incentives due to funding support even though the scope of their activities is only at the educational and coordination stage rather than as a service provider. The village-level confirmed that they also participate in providing personnel and budget for the program. The Mattiro Uleng Village Government said that the village government had integrated the GERTAK program into the village planning and budgeting program through the village budget. The Village Government of Mattiro Uleng requires all newborn babies to obtain a birth certificate immediately before returning home. The current village fund allocation to the program is evidence that the lowest government level (located in the remote island) is significant to help the government achieve service coverage. Currently, there is budget support from village funds around twenty million rupiah to run the GERTAK program at the village level. Support from The Civil Registry Office is also available to strengthen village officials. As seen in the Civil Registry Office budget in 2018, there is a budget of thirty-one million rupiah to increase the capacity of village / sub-districts officials).

This study found some new things that are not found in the Getha-Taylor \&Haddock-Bigwarfe (2014) study. Some of these new conditions are consideration of sustainability, organizational interests, legal framework and reducing bureaucracy. Service innovation by involving various parties is considered profitable because collaboration sets a good innovation precedent, as proven by the multiple awards for bullying programs at the district and provincial levels. Civil Registry Office collaborates with KOMPAK to develop technical instructions in the administrative service program and other service innovations in population administration, aiming to maintain the program's sustainability. The collaboration process is also expected to continue to change society's mindset and bureaucratic work behaviour.

In addition to finding some new considerations, the study found that leader support and contributions from higher capacity organizations did not emerge as the dominant motivation in collaboration. Although the leader's support did not appear as a dominant theme, the informant mentioned that the regulatory framework encouraged them to collaborate. The regulatory framework is a cross-sector cooperation agreement in the GERTAK program that indirectly shows that the leaders of each agency approve collaboration. Support for the legal framework on increasing the scope of civil registration services is also listed in national regulations. Law No. 24/2013 on amendments to the law on population administration stipulates that the ministry, governor, and mayor or regent have the obligation and responsibility of conducting the administrative affairs of the population.

The non-state actors trust the government by synergistically supporting the performance of government actors. However, in the focus group discussion, even though the trust of the state and non-state already increased, several actors, mainly from non-government, expect a higher commitment and coordination from the government. The problem of coordination in collaboration is also found in other research about cooperation in Indonesia. A case study found the challenge of the collaborative process, such as problem in coordination and local government capacity in maintaining collaborative governance with multiple stakeholders, such as the case in the integrated community shelters post-disaster in Palu (Daswati, Samad, \& Wekke, 2020). The discussion found that, apart from the aforementioned factors, the actors considered it necessary to plan and adopt technology to encourage public services and collaboration. The budgeting and planning process should be carried out in detail and included in the regional design draft; the government should also develop network and information technology in Pangkajene and Island Regency for population and civil registration services. The specific approach $\mathrm{s}$ is important considering geographical nature of the region, which consists of islands.

\section{CONCLUSION}

The research found that the urgency to achieve common goals became the often-mentioned condition that encourages the organization to collaborate. While many informants judge that collaboration is to achieve common goals, actors define common goals from various perspectives. Informant thinks that efforts to solve problems are the goals of the partnership. The dynamics of the initial conditions in this collaboration show that the motivation to collaborate at the organizational level is very diverse. In the end, various organizations agree on the same collaboration program.

This research underlines that the involved actors at the local government level already understand the basic definition of collaboration as working with others. The terminology most commonly used to describe efforts to work with other institutions is cooperation. Differences in definitions and 
terminology in factual conditions are similar to fragmentation and varied definitions of collaboration or degrees of collaboration from various experts. The use of words and regulatory frameworks in Indonesia that often introduce forms of work with other agencies as cooperation is very likely to affect the perception and knowledge of each actor on the terminology of collaboration.

The difference in motivation that is judged to encourage this organization confirms that the cause of collaboration must ultimately be influential or influenced by the level of individuals involved. The results of this study ensure that diverse and dynamic initial conditions have the potential to affect the collaboration process. Factual and contextual conditions can affect the differences in the definition of the shared problem of a ministry. Therefore, further research is needed to examine the relationship between perceived problems and motivation for collaboration. Research that can review the desire to collaborate and individual factors from different age groups and positions in the bureaucracy can also be done further.

In line with the results of this research, there are policy recommendations. The dynamics of understanding the urgency of collaboration show that at the organizational and personal level, there need to be adjustments or at least information that is easily accessible to each other to improve the understanding of interested actors. Therefore, strategic planning information in the public sector as various public sectors have widely initiated should involve government and non-government actors. Not only stop at the coordination stage, but policymaking at the organization level will also be maximized if available information and evidence that is easily accessible to all parties, including information on possible collaboration, service issues, and collaboration evaluation.

\section{ACKNOWLEDGMENT}

The authors are grateful for the support of all participants in the project. The author wish to thank the anonymous reviewer for their useful recommendations. Author appreciated Salma Azzahra's assistance in manuscript language editing for analysys part.

This material is based upon the work funded by the Local Autonomy Directorate, the Ministry of National Development Planning, Republic of Indonesia in 2019. The author was a consultant of this research project that advocates in research design development and data collection to nine case study locations including Pangkajene and Island Regency. Any opinions and conclusions are those of the author and do not necessarily reflect the offficial opinion of the Ministry of National Development Planning, Republic of Indonesia.

\section{REFERENCES}

Agranoff, R. (2007). Managing within networks: Adding value to public organizations. Washington
DC: Brookings Institution Press.

Ansell, C., \& Gash, A. (2007). Collaborative governance in theory and practice. Journal of Public Administration Research and Theory, 543-571.

Annissa, M. (2019, November 20). Membangun Asa Desa Tuntas Adminduk di Lombok Timur. Retrieved from KOMPAK: https://kompak.or.id/ id/article/membangun-asa-desa-tuntas-admindukdi-lombok-timur

Bardach, E. (1998). Getting agencies to work together: the practice and theory of managerial craftmanship. Brooking Institution Press.

Bryson, J., Crosby, B., \& Nabatchi, T. (2006). The design and implementation of cross sector collaborations: propositions from the literature. Public Administration Review, 44-55.

Central Bureau of Statistics. (2018). Survei sosial ekonomi nasional (Susenas) (National socioeconomic survey). Jakarta: Central Bureau of Statistics.

Civil Registry Office Metro City . (2020). Inovasi Pelayanan. Retrieved from Disdukcapil Kota Metro: http://dukcapil.metrokota.go.id/Page/ inovasi-pelayanan

Civil Registry Office Denpasar City. (2020, September 01). Kerjasama antara Disdukcapil Kota Denpasar dengan Gojek. Retrieved from Dinas Kependukan dan Catatan SIpil Kota Denpasar: https://www.kependudukan.denpasarkota.go.id/ berita/read/24890\#!

Communication and Information Agency. (2020). Gandeng Disdukcapil, Kades Mattiro Ujung tuntaskan pelayanan adminduk warga. Retrieved from Dinas Komunikasi dan Informatika: https:// diskominfo.pangkepkab.go.id/index.php/berita/ item/1378-gandeng-disdukcapil-kades-mattiroujung-tuntaskan-pelayanan-adminduk-warga

Conner, T., Nowlin, M., Rabovsky, T., \& Ripberger, J. (2015). Cultural theory and managerial values: Examining trust as a motivation for collaboration. Public Administration, 915-932.

Crosby, B., \& Bryson, J. (2005). Leadership for the common good: Tackling public problems in a shared-power world. San Francisco, CA: Jossey-Bass.

Daley, D. (2008). Interdisciplinary problems and agency boundaries: exploring effective cross agency collaboration. Journal of Public Administration Research and Theory 19(3), 477-493.

Daswati, Samad, M., \& Wekke, I. (2020). Collaborative governance in the management of integrated community shelters post disaster (ICS) in the city of Palu. Indonesian Political Science Review 5(2), 229-242.

Directoral General of Popuation and Civil Registry Ministry of Home Affairs. (2020). Keren! 5 Inovasi Dukcapil Masuk Top Sinovik 2020. Retrieved from Dukcapil Kemendagri: https:// dukcapil.kemendagri.go.id/berita/baca/538/ keren-5-inovasi-dukcapil-masuk-top-sinovik-2020 Dwiastono, R., \& Budhi, O. (2019). Pernikahan usia 
anak di Sulawesi Selatan: 'Berikan ijazah, jangan buku nikah' (Child marriage in South Sulawesi: 'Give a diploma, not a marriage certificate'). Retrieved from BBC News Indonesia: https:// www.bbc.com/indonesia/indonesia-49081206

Emerson, K., \& Nabatchi, T. (2015). Collaborative governance regimes. Georgetown University Press.

Emerson, K., Nabatchi, T., \& Balogh, S. (2012). An integrative framework for collaborative governance. Journal of Public Administration Research and Theory 22(1), 1-29.

Esteve, M., Van Witteloostuijin, A., \& Boyne, G. (2015). The effects of public service motivation on collaborative behavior: Evidence from three experimental games. International Public Management Journal, 171-189.

Gazley, B. (2008). Intersectoral collaboration and the motivation to collaborate: toward an integrated theory. In L. Bingham, \& R. O'Leary (Eds.), Big ideas in collaborative public management (pp. 36-54). Armonk, New York: M.E Sharpe.

Getha-Taylor, H., \& Haddock-Bigwarfe, A. (2014). Public service motivation and willingness to collaborate: An examination in the context of homeland security. Evidence-based HRM: a Global Forum for Empirical Scholarship 2(1), 80-95.

Kapucu, N., Garayev, V., \& Wang, X. (2013). Sustaining networks in emergency management: a study of counties in the United States. Public Performance and Management Review, 104-133.

Kaufmann, D., Kraay, A., \& Mastruzzi, M. (2010). The worldwide governance indicators: methodology and analytical issues. The World Bank.

KOMPAK. (2019). Gerakan tuntas administrasi kependudukan (GERTAK) di Kepulauan Pangkep. Retrieved from Kompak: https://kompak.or.id/id/ article/gerakan-tuntas-administrasi-kependudukan-gertak-di-kepulauan-pangkep

KOMPAK. (2020). Panduan fasilitasi kuliah kerja nyata tematik adminduk. Jakarta: KOMPAK.

Kurniawati, I., \& Kustulasari, A. (2020). Public value creation by private sector through crosssector collaboration: A case study of the Gojek Wirausaha Program. Bisnis dan Birokrasi: Jurnal Ilmu Administrasi dan Organisasi, 153-165.

Lynn, L., Heinrich, C., \& Hill, C. (2001). Improving governance: A new logic for empirical research. Washington DC: Georgetown University Press.

Mandell, M., \& Steelman, T. (2003). Understanding what can be accomplished through interorganizational innovations the importance of typologies, context, and management strategies. Public Management Review, 197-224.

Maulana, R. (2020). Collaborative governance in the implementation of e-government based public services inclusion in Jambi Province, Indonesia. Journal of Governance, 91-104.

$\mathrm{Mu}$, R., de Jong, M., \& Koppenjan, J. (2019). Assessing and explaining interagency collaboration performance: a comparatice case study of local governments in China. Public Management Review, 581-605.

Murphy, K. (2015). Does procedural justice matter to youth? Comparing adults' and youths' willingness to collaborate with police. Policing and Society, 53-76.

Nikolova, K., Postmus, J., Buttner, C., \& Bosk, E. (2020). Working together to protect women and children from domestic violence: Factors influencing willingness to colaborate between organizations. Children and Youth Services Review Nugraheny, D. (2020, September 09). Lima Keluhan Masyarakat soal Layanan Administrasi Kependudukan, dari Pungli hingga Lambatnya Pencetakan e-KTP. Retrieved from Kompas: https:// nasional.kompas.com/read/2020/09/09/21165101/ lima-keluhan-masyarakat-soal-

O'Flynn, J., \& Wanna, J. (2009). Collaborative governance: A new era of public policy in Australia. ANU E Press.

O'Leary, R., \& Bingham, L. (2009). The collaborative public manager: New ideas for the twenty first century. Washington D.C: Georgetown University Press.

PANGKEP TV. (2020, January 21). Penerimaan mahasiswa KKN tematik UMI. Retrieved from Pangkep TV: https://www.youtube.com/ watch?v=Fsm9YnTWB6k

Peters, B., \& Pierre, J. (2006). Governance, accountability, and democratic legitimcay. In A. Benz, \& Y. Papadopoulos (Eds.), Governance and Democracy: Comparing National, European and International Experiences. London : Routledge.

Reisig, M., Bratton, J., and Gertz, M., (2007). The construct validity and refinement of process- based policing measures. Criminal Justice and Behaviour 34(8), 1005-1028. doi:10.1177/ 0093854807301275

Serajuddin, U., \& Hamadeh, N. (2020, July 1). New World Bank country classifications by income level: 2020-2021. Retrieved from World Bank Blog: https://blogs.worldbank.org/opendata/ new-world-bank-country-classifications-incomelevel-2020-2021

Statistics of Pangkajene and Island Regency. (2018). Kabupaten Pangkajene Kepulauan Dalam Angka (Regency of Pangkajene Islands In Numbers). Pangkajene: Statistics of Pangkajene and Island Regency.

Sullivan, H., \& Skelcher, C. (2002). Working Across Boundaries: Collaboration in Public Services. Macmillan International Higher Education.

The Ombudsman Republic of Indonesia. (2019). Ringkasan eksekutif: Hasil penilaian kepatuhan terhadap standar pelayanan penyelenggara pelayanan sesuai dengan Undang-Undang Nomor 25 Tahun 2009 tentang Pelayanan Publik (Executive summary: Results of assessment of compliance with service standards of service providers in accordance with Law No. 25 of 2009 on Public 
Services). Jakarta: Ombudsman RI.

Thompson, A., \& Perry, J. (2006). Collaboration processes: Inside the backbox. Public Administration Review, 20-32.

Thompson, G., Frances, J., Levacic, R., \& Mitchell, J. (Eds.). (1991). Markets, hierarchies and networks: The co-ordination of social life. London: Sage.

UNICEF. (2019). Global Databases Birth Registration. UNICEF.

UNICEF. (2020). UNICEF global databases. UNICEF.

Yonavilbia, E. (2020, October 5). Gandeng
Disdukcapil, Kades Mattiro Ujung tuntaskan pelayanan adminduk warga. Retrieved from Info Publik: https://infopublik.id/kategori/nusantara/484985/ gandeng-disdukcapil-kades-mattiro-ujung-tuntaskan-pelayanan-adminduk-warga

Yousefian, S., Sohrabizadeh, S., \& Jahangiri, K. (2021). Indetifying the components affecting intra-organizational collaboration of health sector in disasters: Providing a conceptual framework using a systematic review. International Journal of Disaster Risk Reduction, 1-15. 